\title{
The Discussion on the Revision of the Personnel Cultivating Program of Railway Traffic Operation Management Based on Engineering Education Professional Certification
}

\author{
Sheng Jing, Tang You-ming, Qin Li-yan \\ School of Mechanical and Automotive Engineering, Xiamen University of Technology \\ Xiamen, Fujian, P.R. of China, 361024
}

\begin{abstract}
The formulation and improvement of talent training program has always been the focus of national colleges and universities. Aimed at the problems with the training program of personnel training for the already developed rail transit operation management, a revised method based on education professional certification standard was proposed. On the basis of the core concept of education professional certification, the concept of training mode of transportation professionals was constructed; For rail transit operation management, by analyzing the general standard of education professional certificate, the accurate localization of the profession and the establishment of goal were realized; the graduation requirements of the society on the talents of rail transit were explored and the students' ability, quality and knowledge were planned; The curriculum system was set up on the basis of the supplementary standard of engineering certification; The evaluation methods of the above factors were discussed and the program of talent training was improved; The revised talent training program has worked well after two years of empirical research.
\end{abstract}

Keywords-Railway traffic operation management; Personnel cultivating program; Engineering education professional certification; Revision

\section{INTRODUCTION}

Talent cultivation program is the basis for schools to organize teaching, implement teaching management, and cultivate talents, and also the basis for schools to monitor and evaluate the teaching quality. In order to adapt to the demand of social development for talents under the new form, it has become a new normal for constantly improving talent cultivation program. Lin Jian [1] started from the components of cultivation program, the course system, enterprise cultivation program, the international cultivation of outstanding engineer and other aspects, and put forward solutions and countermeasures for formulating and perfecting talent cultivation program in colleges implementing "excellent plan". Zhu Jian, et al [2]. analyzed the various problems occurred in the talent cultivation program of the school, combined the school-running position and characteristics, and explored the framework of talent cultivation program suitable for its own characteristics. Lai Jianliang, et al. [3] summarized the current status and problems of "dual-certificate system" in higher vocational education, took numerical control major as an example, and pointedly elaborated the construction process of "dual-certificate connection" and "class certificate integration" professional cultivation program. Chang Weiya, et al. [4] analyzed the difficulties highlighted in the innovation capacity cultivation process of college students, and pointedly discussed the course setup for cultivating students' innovation capacity in practical teaching link. As per the positioning of undergraduate education in Chongqing University, Li Liangjun, et al. [5] confirmed cultivation objective, cultivation standard and the realization approach, and reconstructed course system. Zhao Huiqin [6], et al. [6] discussed how to construct professional cultivation program with its own characteristics considering the reposition of application-oriented university. Thus, colleges will regularly or irregularly formulate and constantly perfect talent cultivation program, so as to meet the demand of national economic construction for high-qualified talents.

Urban rail transit is an important direction for contemporary urban transportation development, and the talents requested thereby are mainly cultivated from two majors, i.e., traffic and transportation, traffic engineering. Upon the construction demand of urban rail transit in Xiamen, the traffic and transportation major (rail transit operation management) of our school was set in 2011. Since this major is new, there is no doubt that the talent cultivation program formulated thereby has certain problems; thus, it is planned to revise the talent cultivation program through project research, so as to adapt to the urgent demand of urban rail transit development for talent cultivation.

Fund Project: Education Reform Project for the School of Mechanical and Automotive Engineering, Xiamen University of Technology (2015JQYJG03).

[About the Author] Sheng Jing (1965.1-), male, born in Wuchang, Hubei, and the Professor of Xiamen University of Technology, mainly studying traffic and transportation safety, smart manufacturing, and computer integrated manufacturing technology

Email: shengqqqqjing@163.com 


\section{PROBlems EXISTED IN THE Formulation PROCESS OF TRAFFIC OPERATION MANAGEMENT TALENT CULTIVATION PROGRAM}

Many colleges at home (Jilin University, Tongji University, Southeast University, Southwest Jiaotong University and Beijing Jiaotong University) and even Fujian Fuzhou University, Fujian Agriculture and Forestry University, Fujian University of Technology have set traffic engineering or traffic and transportation major. In undergraduate colleges setting majors oriented to "rail transit operation management", our school is the second one after Shanghai University of Engineering Science. The formulation of talent cultivation program has the following problems:

\section{A. Insufficient understanding on the cultivation system of traffic and transportation majors}

Since the traffic and transportation major of the school hasn't been set before, and few teachers graduate from this major, we are lack in the overall understanding on the system of the major, causing unclear major positioning, dim understanding on the cultivation objective as well as hardly described and condensed major characteristics, so the overall grasp of talent cultivation program is inaccurate.

\section{B. Undefined Cultivation Standard}

For quite a long time, there are few standards related to the formulation of talent cultivation program, and this has caused limited and unspecific cultivation standard; meanwhile, when formulating talent cultivation program, analogy method or transplantation method is generally adopted, so it is hard to avoid the trace of copying and applying mechanically. The partial expressions about the cultivation objective and cultivation specification are relatively dim, with weak pertinence; meanwhile, the conformity of cultivation objective and cultivation specification isn't high.

\section{Weak strength in cultivating students' comprehensive capacity, quality and knowledge}

Since the correlation between the cultivation specification and the cultivation of students' quality, capacity and knowledge is relatively weak, the specific capacity, quality, and knowledge descriptions are abstract, and the realization approaches or link expressions are not detailed, especially the shortage of the capacity in solving complicated engineering problems, and innovation capacity expression, the students cultivation effect cannot reach to the professional expectation.

\section{Bad integrity and systematicness of course system}

At the initial period for the formulation of talent cultivation program, the talent cultivation programs of domestic colleges and overseas colleges have been extensively collected; meanwhile, transplantation and cohesion mode is adopted; even though the formulation is made as per "three-three-three system" (investigating three domestic colleges, three enterprises and three domestic (overseas) colleges) principle, the course system set thereby is still barely satisfactory.

\section{PROGRAM FOR FORMULATING THE TALENT CUlTivation PROGRAM}

Engineering education professional certification can provide a new solution for talent cultivation. It takes engineering education certification as the standard and the basis, and then closely centers on the undergraduate talent cultivation mode of traffic engineering major (rail transit direction), and carries out work involving the following aspects.

\section{A. Talent Cultivation Objective and Evaluation Standard for Traffic Operation Management Major}

On the basis of studying the core concept of engineering education professional certification, it is requested to build the concept and principle for the talent cultivation mode of traffic and transportation major. As per the concept of engineering education certification and the general standards for engineering education certification, through visiting schools and enterprises, and on the basis of understanding the social demand, the graduates employment conditions and working performance in combination with the school-running concept of "student-oriented, and serving the industry" in our school as well as the school-running positioning of "open type, application type, locality, internationalization, and industry orientation", and referring to the previous cultivation objective, it is requested to put forward the talent cultivation objective for rail transit operation management in our school: this major cultivates senior application-oriented talents that can adapt to the development demand of Western Taiwan Straits Economic Zone, especially Xiamen economic, and urban rail transit fields, and meanwhile, (1) possess healthy personality, healthy mind and body, (2) possess social sense of responsibility, and professional moral quality, (3) solid professional theory basis and engineering knowledge, (4) familiar with modernized and professional technical tools, (5) master engineering practice analysis evaluation method in society, economy, safety, environment and other aspects, (6) possess international vision, innovation consciousness, lifelong learning, team cooperation, communication and other capacities, (7) and can be engaged in the research, urban rail system planning design and analysis, operation organization, operation management and other work of the major field, (8) and can also gradually become the technical elites (backbones) or middle and high level of management experts of the field. The 12 graduation requirements stipulated in the general standards for engineering education professional certification are adjusted to 12 graduation requirements for the major and they are regarded as the evaluation standard.

\section{B. Graduation Requirements and Capacity, Quality and Knowledge Expression}

As per the general standards for the talent cultivation objective, and the engineering education certification, supplemented by the cultivation specification, professional core knowledge, capacity and quality requirements for the previous edition of talent cultivation program, 12 professional graduation requirements are put forward; as for the support relation of graduation requirements in cultivation objective, please refer to Table 1; thus, it has put forward the 
corresponding cultivation standards (capacity, quality and knowledge), construct the cultivation standard for traffic transportation major (rail transit operation management direction), and define the incidence relation between "cultivation objective" and "graduation requirements"; please refer to Table 2 .

TABLE I. SUPPORT RELATION OF GRADUATION REQUIREMENTS IN THE REALIZATION OF PROFESSIONAL CULTIVATION OBJECTIVE

\begin{tabular}{|c|c|c|c|c|}
\hline & Cultivation Objective 1 & Cultivation Objective 2 & $\ldots \ldots$ & Cultivation Objective 8 \\
\hline Graduation requirements 1 & $\sqrt{ }$ & $\sqrt{ }$ & & \\
\hline Graduation requirements 2 & $\sqrt{ }$ & & $\sqrt{ }$ & $\sqrt{ }$ \\
\hline$=$ & $=$ & $=$ & $=$ & $=$ \\
\hline Graduation requirements 12 & $\vec{V}$ & $\vec{V}$ & $\ldots$ & $\vec{V}$ \\
\hline
\end{tabular}

TABLE II.

CULTIVATION STANDARD OF TRAFFIC AND TRANSPORTATION MAJOR (RAIL TRANSIT OPERATION MANAGEMENT DiRECTION)

\begin{tabular}{c}
\hline Graduation Requirements \\
\hline \\
1. Engineering knowledge: be \\
capable of using mathematics, \\
natural science, engineering \\
foundation and professional \\
knowledge to solve \\
professional complicated \\
engineering problems of \\
traffic engineering.
\end{tabular}

\section{$\equiv$}

12. Lifelong learning: Possess the awareness of autonomic learning and lifelong learning, and the capacity of learning continuously and developing adaptively.
Knowledge, Capacity and Quality

Possess relatively solid foundation in mathematics and other relevant natural science knowledge.

Master the relevant knowledge about dynamics, electrotechnics and electronics, etc.

Master operation research, management, traffic and transportation organization and other basic theories and knowledge.

Learn the thinking method of using computer to analyze and solve problems, and master the basic methods of program design.

\section{$\equiv$}

Cultivate students' capacity in using various means to obtain data, information, and track the newest technical development trend of the field.
Link or Approach for Realization

Advanced Mathematics I, College Physics I (I), College Physics I (II), Linear Algebra I, Probability and

Mathematical Statistics I, and Statistics

Engineering Mechanics I, Electrical and Electronic Technology, Integrated Electronic Practice for Electricians

Operational Research, Management Principle, Management Information System, Transportation Organization, and Traffic Planning Theory and Methods

Foundation of Computer Application Technology II, CC

Language Program Design II, and VFP Database Program Design

$$
\bar{\Sigma}
$$

Computer Course Design, Urban Rail Running Organization Course Design, Passenger Entrance and Exit Organization

Design Course Design, Urban Rail Transit Safety and Emergency Design Course Design, and Graduation Design (Thesis)

\section{Setup of Course System}

As per the characteristics of the major, confirm the support discipline: traffic engineering system, and system engineering. Through focusing on the national standards for the teaching quality of traffic and transportation major and the supplementary standard of engineering education certification, normalize professional core courses as follows: Traffic System Engineering, Traffic Engineering Introduction Theory, Traffic Flow Theory, Road Capacity and Service Level, Traffic Planning, Traffic Design, Traffic Management and Control, Traffic Safety, Traffic Economy, Public Traffic, Smart Traffic System, Traffic Post and Hub, Traffic Demand Management, Traffic and Transportation Policy and Regulations as well as other courses. The main practical teaching links include: Urban Traffic Hub Course Design, Urban Rail Transit and Passenger Transport Organization Course Design, Urban Rail Transit Running Organization Course Design, Urban Rail Signal and
Communication Practice, Urban Rail Transit and Transportation Equipment Application Practice, Urban Rail Transit Running Organization Practical Training, Urban Rail Transit and Passenger Traffic Organization Practical Training, Graduation Practice and Graduation Design and other courses. As per the guidance policy of "focusing on foundation, widening caliber, emphasizing on practice, and being skilled at application", construct professional course system, plan for public basic course, professional basic course, professional course, professional optional course, etc.; for the credit hour and credit structure of various course modules, please refer to Table 3. On the basis of analyzing the internal relation among the graduation requirements, the capacity, quality and knowledge as well as the course system, construct the matrix about the graduation requirements and cultivation standard as well as the link or approach for realization is built, which is as shown in Table 4. 


\begin{tabular}{|c|c|c|c|c|c|c|c|}
\hline & \multirow{2}{*}{\multicolumn{2}{|c|}{ Course Type and Property }} & \multirow{2}{*}{\multicolumn{4}{|c|}{ Credit Hour }} & \multirow[b]{2}{*}{ Credit } \\
\hline & & & & & & & \\
\hline & & Public basic course & $\begin{array}{c}\text { Lecture } \\
726\end{array}$ & $\begin{array}{c}\text { Practice } \\
312\end{array}$ & $\begin{array}{c}\text { Others } \\
48\end{array}$ & $\begin{array}{r}\text { Total } \\
1086\end{array}$ & 63 \\
\hline & Compulsory & Public professional basic course & 635 & 52 & & 687 & 43 \\
\hline \multirow{4}{*}{ In-class teaching } & \multirow{4}{*}{ Optional } & Professional course & 328 & & & 328 & 21 \\
\hline & & Professional optional course & 768 & & & 768 & 4 \\
\hline & & Public optional course & 128 & & & 128 & 8 \\
\hline & & Subtotal & 2585 & $A=364$ & 48 & 2997 & 175 \\
\hline \multicolumn{3}{|c|}{ Independent setup of practical teaching link } & \multicolumn{4}{|c|}{ Totally 35 weeks } & $\mathrm{B}=35$ \\
\hline \multicolumn{3}{|c|}{ Innovation practice and quality expansion link } & & & & & $\mathrm{C}=3$ \\
\hline
\end{tabular}

Proportion of practical teaching credit in total credit $=[(\mathrm{A} / 16+\mathrm{B}+\mathrm{C}) /$ total credit $] * 100 \%=[364 / 16+35+3] / 178 * 100 \%=33.7 \%$

TABLE IV. INCIDENCE MATRIX OF GRADUATION REQUIREMENTS AND COURSES

\begin{tabular}{|c|c|c|c|c|c|c|}
\hline Graduation Requirements & $\begin{array}{c}\text { Knowledge, Capacity and } \\
\text { Quality }\end{array}$ & $\begin{array}{c}\text { Advanced } \\
\text { Mathematics I }\end{array}$ & $\begin{array}{l}\text { Transportation } \\
\text { Organization }\end{array}$ & $\begin{array}{l}\text { Traffic Planning } \\
\text { Theory and } \\
\text { Methods }\end{array}$ & $\begin{array}{l}\text { VFP Database } \\
\text { Program } \\
\text { Design }\end{array}$ & $\ldots \ldots$ \\
\hline $\begin{array}{l}\text { 1. Engineering } \\
\text { knowledge: be capable } \\
\text { of using mathematics, } \\
\text { natural science, } \\
\text { engineering foundation } \\
\text { and professional } \\
\text { knowledge to solve } \\
\text { professional } \\
\text { complicated } \\
\text { engineering problems } \\
\text { of traffic engineering }\end{array}$ & $\begin{array}{l}\text { Possess relatively solid } \\
\text { foundation in mathematics } \\
\text { and other relevant natural } \\
\text { science knowledge. } \\
\text { Master the relevant } \\
\text { knowledge about } \\
\text { dynamics, electrotechnics } \\
\text { and electronics, etc. } \\
\text { Master operation research, } \\
\text { management, traffic and } \\
\text { transportation } \\
\text { organization and other } \\
\text { basic theories and } \\
\text { knowledge. } \\
\text { Learn the thinking method } \\
\text { of using computer to } \\
\text { analyze and solve } \\
\text { problems, and master the } \\
\text { basic methods of program } \\
\text { design, and master the } \\
\text { basic methods of program } \\
\text { design. }\end{array}$ & $\sqrt{ }$ & $\sqrt{ }$ & (1) & - & $\ldots \ldots$ \\
\hline
\end{tabular}

\section{Evaluation of Cultivation Objective, Cultivation Standard and Course Teaching Quality}

Objective cultivation, cultivation standard and cultivation system also have a continuous improvement process, which requests them to have responsive evaluation method. In consideration of the cultivation objective and the cultivation standard (graduation requirements, capacity, quality and knowledge) layer structure relation, the evaluation of index layer (capacity, quality and knowledge) can be participated by schoolmates, graduates, employers and industrial experts, and then by virtue of the analytic hierarchy process [7], construct evaluation matrix layer by layer, confirm the weight of multilayer projects (refer to Table 5), and then adopt fuzzy 
evaluation method to respectively evaluate the cultivation objective, and cultivation standards, and the evaluation standard shall be regarded as the basis for improvement. The evaluation of teaching quality for various courses can be evaluated through setting the achievement ratio of various teaching activity measures, which shall be regarded as the basis for improving the course teaching quality.

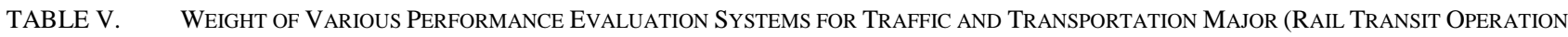
MANAGEMENT)

\begin{tabular}{|c|c|c|c|}
\hline $\begin{array}{c}\text { Graduation } \\
\text { Requirements } \\
\text { (Criterion Layer) }\end{array}$ & $\begin{array}{l}\text { Criterion } \\
\text { Weight }\end{array}$ & $\begin{array}{l}\text { Capacity, Quality and Knowledge } \\
\text { (Index Layer) }\end{array}$ & $\begin{array}{l}\text { Index } \\
\text { Weight }\end{array}$ \\
\hline \multirow{5}{*}{$\begin{array}{l}\text { 1. Engineering } \\
\text { knowledge }\end{array}$} & \multirow{4}{*}{0.0305} & $\begin{array}{l}\text { a. Possess relatively solid foundation in mathematics and other relevant natural science } \\
\text { knowledge }\end{array}$ & 0.2442 \\
\hline & & b. Master the relevant knowledge about dynamics, electrotechnics and electronics, etc. & 0.1221 \\
\hline & & $\begin{array}{l}\text { c. Master operation research, management, traffic and transportation organization and } \\
\text { other basic theories and knowledge }\end{array}$ & 0.1452 \\
\hline & & $\begin{array}{l}\text { d. Learn the thinking method of using computer to analyze and solve problems, and } \\
\text { master the basic methods of program design }\end{array}$ & 0.4884 \\
\hline & & .... & . \\
\hline$\equiv$ & $\equiv$ & $\equiv$ & $\equiv$ \\
\hline $\begin{array}{l}\text { 12. Lifelong } \\
\text { learning }\end{array}$ & 0.0379 & $\begin{array}{c}\text { c. Be capable of constantly checking the personal development demand, formulating and } \\
\text { implementing the study plan of continuous development }\end{array}$ & 0.1602 \\
\hline
\end{tabular}

\section{ANALYSIS ON THE CHARACTERISTICS OF TALENT CULTIVATION PROGRAM FORMULATED UNDER THE ENGINEERING EDUCATION PROFESSIONAL CERTIFICATION}

The revised professional training objective has increased the requirements for students' innovation capacity, and international vision as well as the expected requirements for the career of students after their graduation, and meanwhile, reflected the school discipline, industrial characteristics and regional characteristics; the former cultivation specifications include 8 articles, but currently, we have 12, which have not only defined the former projects, but also expanded personal communication capacity, team cooperation awareness, modernized tool application, complicated engineering issues solving capacity and the requirements of other aspects; they can focus on the combination of theory and practice as well as the capacity of comprehensively solving engineering problems, and then start from the professional graduation requirements, and expand to the knowledge, capacity and quality that shall be equipped in the field, industry and even the world; the graduation requirements and knowledge, capacity and quality as well as the link and approach for realization can establish the relevance through constructing matrix; since hierarchical structure description is adopted, the cultivation objective, graduation requirements and other layers shall be evaluated through the method of using other layers and adopting fuzzy theory, and the various items of any layer can be evaluated with the achievement rate. The revised talent cultivation program system is complete, with strong systematicness, and the various indexes cannot only be qualitatively described, but also be quantitatively evaluated.

\section{CONCLUSION}

The talent cultivation program based on engineering education professional certification standard can play an important role in cultivating senior application talents recognized by various parties. Taking the traffic and transportation major of our school as an example, we have revised the existing talent cultivation program, and then through comparing and revising the former cultivation program, it has been found out that the revised cultivation program is more comprehensive, scientific, and delicate, and has been recognized by various parties. With two years after the revised cultivation program was operated, the efficiency has obtained the wide recognition of students, teachers and enterprise peers. Thus, through studying this project, certain research achievements are obtained in the talent cultivation mode research under engineering education professional certification, and they have guided the revision of talent cultivation program for the traffic and transportation major of our school (rail transit direction), the management measures, and formulation perfection afterwards; meanwhile, we have also gradually formed our own professional characteristics, and laid a foundation for the traffic and transportation major of our school to realize a great-leap-forward development. 


\section{REFERENCES}

[1] Lin Jian. Restudy on "Excellent Engineering Education Training Plan" Professional Cultivation Program [J]. Researches in Higher Education of Engineering, 2011(4): 10-17.

[2] Zhu Jian, and Liu Juqin. Reform of Talent Cultivation Program and Cultivation of High-qualified Application-oriented Talents [J]. China Higher Education, 2014(5):59-60.

[3] Lai Jianliang, $\mathrm{Tu} \mathrm{Li}, \mathrm{Du}$ Hongwen, et al. Construction and Implementation of "Dual-certificate Connection" Talent Cultivation Program for Higher Vocational Education-Taking Mechanical Major as an Example [J]. Researches in Higher Education of Engineering, 2013(5): 123-126.
[4] Chang Weiya, Zhao Li, Zhu Chenwei, et al. Including Innovation Teaching into the Undergraduate Cultivation Program [J]. China Higher Education, 2016(2):50-52.

[5] Li Liangjun, Yi Shuping, Yan Xingchun, et al. Excellent Plan Cultivation Program for Research Undergraduate Colleges_- Taking the undergraduate Mechanical Engineering and Automation Major of Chongqing University as an Example [J]. Researches in Higher Education of Engineering, 2013(3):46-50.

[6] Zhao Huiqin, Liu Zhihua, and Yuan Huting. Research on the Talent Cultivation Program for the Education Technology Major of Application-oriented Undergraduate College [J]. Theory and Practice of Education, 2016(15):15-17.

[7] T L Saaty. The analytic Hierarchy Process: planning, Priority Setting, Resource Allocation [M]. New York: Mc Graw Hill. 1980. 